\title{
Why President Trump's Claim He Can Do Away with Natural Born Citizenship is False!
}

\author{
Vincent J Samar* \\ Associate Graduate Faculty Member, Loyola University, Chicago \\ Submission: January 15, 2019; Published: February 08, 2019 \\ "Corresponding author: Vincent J Samar, Associate Graduate Faculty Member, Graduate School, Loyola University Chicago
}

\section{Opinion}

President Trump recently claimed just prior to the midterm elections that he has the authority to issue an executive order to do away with the Fourteenth Amendment's provision for natural born citizenship presumably to discourage illegal immigration for the purpose of affording a U.S. birth. That claim is simply false. It reflects a serious lack of understanding of what constitutions do or how our constitutional order works.

A constitution is a social contract between the people to create a government. The U.S. Constitution, ratified in 1788, replaced the prior Articles of Confederation, which was seriously deficient in resolving interstate problems. The new Constitution provided for a central government with separate legislative, judicial and executive branches and specified the range of each branch's authority. The Articles had only provided for a Congress to act unanimously and as a result could seldom get things done. The specification of authority was important because at the time many feared that replacing the Articles with a too strong central government might abridge the authority of existing state governments and individual rights. Indeed, as part of the assurance that this should not happen, the proponents of the Constitution promised as its first order of business that the new Congress would propose to the states for ratification a Bill of Rights to ensure state authority and individual liberty. Currently there are 27 amendments.

In 1868, the United States adopted the Fourteenth Amendment to be part of its Reconstruction Amendments following the Civil War. That Amendment provides in relevant part: "All persons born or naturalized in the United States, and subject to the jurisdiction thereof, are citizens of the United States and of the State wherein they reside." Being subject to jurisdiction means being subject to the laws of the United States, which clearly most people residing in the United States are subject. The children of a diplomat born in the United States are not automatically citizens because the parent is only present as a representative of a foreign sovereignty (See U.S. v. Wong Kim Art, 169 U.S. 649 [1898]).

Native Americans including their children were not originally considered to be citizens under the 14th Amendment because their tribes constituted separate sovereignties existing within the territorial limits of the U.S. that unlike the states had not participated in the Constitution's creation (See Elk v. Watkins, 112 U.S. 94 [1884]). In 1924, Congress granted Native Americans citizenship with the Indian Citizenship Act. Nowhere does the 14th Amendment allow either the President or the Congress any say in whether a person born in the United States is a citizen of the United States. Congress, but not the President, does have a role in naturalization under Article 4, Section 8 of the original Constitution but not over the citizenship of native-born persons. Consequently, President Trump's claim that he has authority to do away with natural born citizenship is contrary to the literal language of the Amendment and to the way the Constitution operates to assign only certain powers to the various branches of government.

There is a way to change the Fourteenth Amendment, although I am certainly not advocating it and believe it would be contrary to the ideals of the Amendment. Under Article 5, either two-thirds of both Houses of Congress or two-thirds of the several states by convention can propose changes to the Constitution. Three fourths of the several states would then have to ratify the change. If President Trump really wants to change the Fourteenth Amendment that would be the way, he would have to go. 
Your next submission with Juniper Publishers will reach you the below assets

- Quality Editorial service

- Swift Peer Review

- Reprints availability

- E-prints Service

- Manuscript Podcast for convenient understanding

- Global attainment for your research

- Manuscript accessibility in different formats

( Pdf, E-pub, Full Text, Audio)

- Unceasing customer service

Track the below URL for one-step submission https://juniperpublishers.com/online-submission.php 